Research Article

\title{
Experimental Characterization of Traditional Mortars and Polyurethane Foams in Masonry Wall
}

\author{
Dora Foti $\mathbb{D}^{1},{ }^{1}$ Michela Lerna, ${ }^{2}$ and Vitantonio Vacca ${ }^{1}$ \\ ${ }^{1}$ Department of Civil Engineering and Architecture, Polytechnic of Bari, Via Orabona 4, 70125 Bari, Italy \\ ${ }^{2}$ Department of Innovation Engineering, University of Salento, Via per Monteroni, 73100 Lecce, Italy \\ Correspondence should be addressed to Dora Foti; dora.foti@poliba.it
}

Received 6 June 2018; Revised 9 July 2018; Accepted 17 July 2018; Published 19 August 2018

Academic Editor: Pietro Russo

Copyright (c) 2018 Dora Foti et al. This is an open access article distributed under the Creative Commons Attribution License, which permits unrestricted use, distribution, and reproduction in any medium, provided the original work is properly cited.

Masonry is a composite material largely used in construction. It exhibits several advantages, including significant compressive strength, thermal inertia, and aesthetic beauty. A disadvantage of masonry is mainly related to the inadequate shear strength due to the poor capacity and ductility of the adopted mortar. This aspect is crucial in seismic areas. In this paper, the behavior of polyurethane foams, used as adhesives for the construction of thin joints brick masonry walls, has been investigated. First, the characterization of components was carried out, followed by laboratory uniaxial tests on masonry walls and shear tests on triplets. Moreover, a comparison of the behavior of the foam-brick walls with respect to the traditional mortars masonry was carried out, as the type of joints varies and the arrangement of the holes of the bricks varies with respect to the direction of the applied load. Results provide indications on which adhesive has to be adopted for masonry buildings in reference to the site of construction (i.e., seismic hazard).

\section{Introduction}

Masonry is one of the oldest building systems that characterized the history of the structures. Although it consists in the coworking of two constituents, such as the brick and the mortar, arranged in a more or less regular texture, the role of the mortar joints is currently slightly investigated in the scientific literature. An explanation for this is attributable to the common responsibility of the masonry structural members: the mechanical performance of the mortar is less important when compared to the compressive strength of the brick (natural or artificial). In the past centuries, masonry structures were designed by considering death loads. The choice of the type of brick and its dimensions were the main target of the structural calculus. Unfortunately, recent seismic events have shown that masonry elements hardly effectively react against horizontal forces (e.g., in earthquakes). This is principally devoted to the existing mortar in the masonry. In fact, brittle failure easily occurs within the mortar joints when an in-plane force is applied. In this scenario, more efforts need to be concentrated on the study of the mechanical performances of traditional mortars and even more on innovative once.
Similarly, since the twentieth century, the construction industry had been more prone towards the use of reinforced concrete for structures with infills. In addition, after the past seismic events, such as L'Aquila earthquake (2009), masonry showed a very brittle behavior and a diffused crack patterns even if included in reinforced concrete frames. As a consequence, many buildings were declared nonaccessible although the structure remained apparently intact. Today, new technologies have revived the masonry built with thin joints [1-6]. Moreover, further studies regarding the behavior of thin joints in presence of fiber-reinforced mortars have been developed. The mechanical characteristics of the masonry made with bricks and thin joints have been compared by means of laboratory tests on panel specimens $[7,8]$. This kind of fiber-reinforced mortar has been also successfully utilized for the reinforcement of concrete columns [9] or other concrete members [10-13].

In seismic prone areas, thin joints become important elements in a masonry structure, being shear strength the main parameter connected with the earthquake resistance of a masonry. Increasing the shear strength of the masonry mainly concerns the execution of proper bed and head joints as this provides stiffness to the structure [14-16]. For this 
kind of joints, polyurethane foams can also be used to make up a wall. They are more deformable and ductile and show a higher damping capacity than traditional mortars. This aspect makes the foams more performable in seismic prone areas; however, this characteristic should be verified with respect to traditional mortars, as aimed in the present paper for thin joints brick masonry walls.

\section{Background}

Due to their versatility and ease of use, polyurethane foams are suitable to be effectively used in masonry walls; they present, in fact, a series of advantageous characteristics, such as excellent adhesion to substrates of various nature, extreme speed of installation, and strong reduction in processing costs and, consequently, in the total costs.

Several studies have been conducted on the use of foams as filler for sandwich panels [17-19]. The cores have been realized with different kinds of polyurethane foams and their mechanical characteristics have been compared.

Furthermore, the structural behavior of a prefabricated wall system made up of glass fiber-reinforced rigid polyurethane foam (PUF) and magnesium oxide (MgO) has been investigated. The experimental results showed a behavior governed by $\mathrm{MgO}$, while a complete interaction between the fiber-reinforced rigid polyurethane foam and $\mathrm{MgO}$ board was achieved by using epoxy adhesives [20].

Taher et al. [21] assessed the crashworthiness characteristics of a composite glass fiber-reinforced plastic (GFRP) sandwich structure with the purpose of producing costeffective sandwich structures. All the samples were based on the concept of the "double-layered" foam-filled block. Thus, two foam-core sheets are wrapped by reinforcement woven fabric; the latter acts as a reinforcement face and at the same time ties the core layers and faces together, thus preventing catastrophic failure under axial loading conditions. Experimental results indicated that a high crushing force efficiency was achieved.

Moreover, the metal foams have relatively recently found applications in construction, automotive, aerospace, and naval industries due to their unique properties, such as excellent stiffness-to-weight ratio, efficient energy absorption, shock wave attenuation, sound and vibration damping, and absorption and low thermal conductivity. The mechanical properties of the aluminum foam-polymer composites were also studied [22-25].

An interesting application regards the use of polyurethane within plaster by incorporating different proportions of the recycled polyurethane itself [26]. The objective of the conducted experimentation was to obtain a new lightweight plaster material with good thermal insulating properties for industrial applications. Also, the properties of the mix and the basic proportions to get the desiderate behavior have been determined. The experimental results showed that the quantity of polymeric foam present in the composite is the most important factor in explaining the variation in the properties of these compounds.

The behavior of masonry prisms under axial compression is influenced by the relative stiffness of masonry units and mortar, the thickness of mortar joints, and the shape of the units. Thamboo et al. [27] presented an experimental study carried out to examine the effects of the thickness of mortar joints, the type of mortar adhesives, and the presence of shells in the hollow concrete masonry prisms under axial compression test. It is found that the thinner and higher adhesive mortars increase the compressive strength and stiffness, while lowering Poisson's ratio.

A large experimental campaign regarded the investigation of the mortar composition effect, the dispersion methods, and the unit surface textures when flexural and shear bond characteristics is the main issue [28]. The results of the flexural and shear bond characteristics about the thinlayer polymer cement mortared concrete masonry evidenced the effectiveness of the polymers in significantly improving the mechanical performances of the masonry. A further study aimed to investigate the influence of the curing methods, and the age of the bond has been performed. As a result, the dry cured thin-layer mortared masonry exhibited higher bond strength and Young's and shear modules when compared to the wet cured specimens [29].

An experimental campaign has been conducted to analyze the behavior of a thin-layer polymer mortared concrete masonry under combined shear-compression stress state [30]. Similarly, to the conventional masonry, its strength and deformation were affected by the orientation of the bed joints to the direction of the applied loading. Nevertheless, the thin-layer mortared concrete masonry showed trending towards isotropic behavior compared with conventional masonry, which is distinctly orthotropic.

A finite element technique for high bond strength, thinlayer mortared masonry through material and interface modelling for simulating the behavior of the masonry was proposed in [31]. The developed interface model consistently simulates the behavior for masonry joints, which dominates many modes of failure of the masonry. In the study, the joint strength to shear and flexural actions were modelled and the agreement with the experimental results was accurate.

Finally, experimental and numerical investigations were conducted to evaluate the influence of the bond strength on the in-plane shear capacity of masonry walls [32]. The study figured out that the polymeric joints benefitted the masonry in favouring the failure in the brick units. Currently, very few studies specifically refer to the polyurethane foams utilized in bonding material for buildings' walls. Foams could be very useful in seismic areas; due to the ductility, they can assess to the joints and, therefore, to the entire masonry building. From this point of view, foams should be preferable with respect to ordinary bonding materials and adhesives. With this in mind, the present research consists in the characterization of the properties of the materials constituting the masonry made with thin joints from the experimental point of view by considering innovative and traditional adhesives, that is, polyurethane foams and mortar, respectively.

\section{Experimental Program}

After a preliminary study on the characteristics and classification of mortars according to the Italian Technical 
Standards for Construction (DM 2008) [33], a series of laboratory tests have been performed aimed at highlighting the mortar-brick and foam-brick forces of adhesion and adherence [34]. The aim is a possible comparison between mortars and foams also based on the kind of joints and the different brick blocks used during the tests.

The specimens were assembled with rectified brick blocks $(35 \times 24.5 \times 24 \mathrm{~cm})$. The results have been discussed, highlighting the advantages and disadvantages of the two bonding solutions.

The main goal of the proposed study consists in evaluating the mortar role in the mechanical characterization of the masonry by varying the type of mortars. For this purpose, the adopted mortars itself have been tested, as well as the masonry in shear-stress state and the adhesion of the mortar with the brick. In order to clearly report the methodology, the experimental program has been arranged by reporting three different sections regarding the mortar, the block, and the masonry tests, respectively. Finally, the main results are presented and discussed by comparing the experienced performance of the traditional and innovative mortars. The mechanical characteristics have been computed according with Italian and International standard test methods.

3.1. Mortars. Foam can be described as a stable structure with low density and strong cohesion. In this study, only treated polyurethane foams, one-component based, usually available in spray cans have been considered. The polyurethane foam is a mixture of polyurethane prepolymer and propellant. Thus, polyurethane foams have a number of characteristics that make them suitable for many different applications, for example, in excellent adhesion and outstanding insulation ability against heat, cold, and noise. Furthermore, they present high durability when chemical agents are in contact, elasticity, and ability to absorb shocks. In addition, for their versatility and ease of use, polyurethane foams are well suited to be used in the building field. The main applications are the thermal insulation of window frames, the thermal insulation of water pipes and thermohydraulic installations, fixing insulating panels (polystyrene, polyester, cork, etc.), the consolidation of tiles, the bonding of metal sheets and tiles for roof covering, and so on.

The mortars utilized for comparison purposes are M1mortar (i.e., mortar composed of cement and fine-graded mineral fillers, containing high quantities of synthetic resins and special additives; shear adhesion of $2.0 \mathrm{MPa}$ ), M2mortar (i.e., mortar based on silicates and carbonates; shear adhesion of $2.5 \mathrm{MPa}$ ), and $\mathrm{M} 3$-mortar (i.e., special mortar for brick blocks with a good thermal insulation; shear adhesion of $2.7 \mathrm{MPa}$ ).

One of the fundamental properties of the mortar joints in masonry texture is the adhesion strength, which can be experimentally measured according to [35]. In particular, the adhesion strength is obtained by means of the pull-out method and specific tests on masonry samples. The sample is rigidly held and a clamp is fixed to the upper part. A bending moment is applied to the clamp with a lever until when the upper part is pulled out (Figure 1).

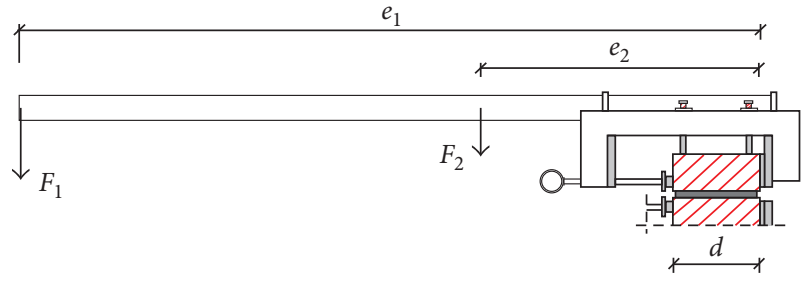

FIGURE 1: Sketch of the pull-out test method.

The nomenclature related to Figure 1 is listed as follows:

(i) $e_{1}$ : distance between the point of application of the load and the connecting system $(\mathrm{mm})$

(ii) $e_{2}$ : distance from the center of gravity of the lever and the connecting system $(\mathrm{mm})$

(iii) $F_{1}$ : maximum applied load $(N)$

(iv) $F_{2}$ : weight of the lever and the upper connecting system $(N)$

(v) $d$ : average depth of the sample.

Here, the adhesion force is obtained according to the following equation:

$$
f_{\mathrm{wi}}=\frac{F_{1} e_{1}+F_{2} e_{2}-(2 / 3) d\left(F_{1}+F_{2}+(W / 4)\right)}{Z},
$$

where

$$
Z=\frac{b d^{2}}{6},
$$

where $b$ is the average width of the tested joint; $d$ is the average depth of the specimen; and $W$ is the weight of the masonry unit obtained from the specimen with the mortar.

The first series of laboratory tests consisted of two vertical compression tests on blocks joined in the direction parallel to the holes by means of polyurethane foam. Each specimen has been realized with 2 Module FV "MVI350" type brick blocks (Figure 2). By following the instructions about the use of the foam, two parallel curbs, of about $3 \mathrm{~cm}$ thick each (thin joints), were realized and then positioned at a distance of about $5 \mathrm{~cm}$ from the edge of the block (Figure 3 ). The hardening of the foam required only one hour; however, three days more have been spent before testing in order to be sure about the hardening of the bonding materials.

Table 1 reports the results for specimens made with two rectified bricks and foam.

Furthermore, a second series of tests have been done utilizing Gasbeton (i.e., autoclaved aerated concrete) elements and foam for comparison purposes (Table 2).

Figures 4 and 5 show, respectively, A4 failure and A7 failure occurred in this test.

Results show that higher performances are obtained in the case of specimens made with Gasbeton elements.

In addition, compression tests on a couple of bearing bricks, set in the direction of the holes, have been carried out. A comparison between the values obtained for different kinds of adhesives and joints has also been developed. In particular, 30 pairs of samples have been realized 


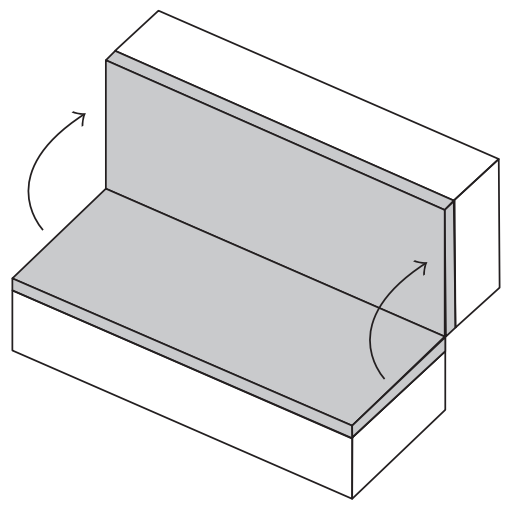

Figure 2: Failure A4: insufficient stress inside the joint.

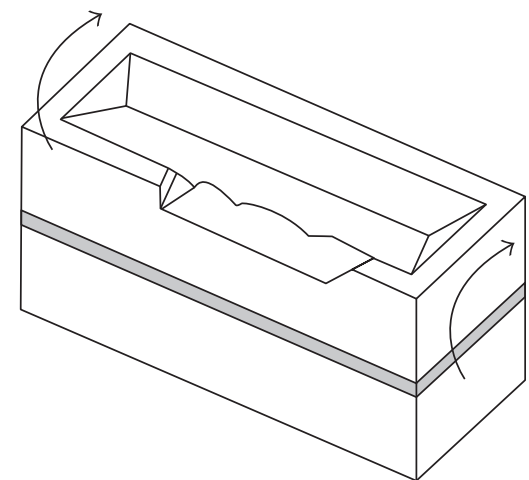

FIgURE 3: Failure A7: shear crash of the part of the specimen fixed to the clamp.

TABle 1: Specimen 1: rectified brick $37 \times 25 \times 23.5 \mathrm{~cm}$ and foam for masonry.

\begin{tabular}{lcccccc}
\hline $\begin{array}{l}\text { Test } \\
\text { number }\end{array}$ & $\begin{array}{c}F_{1} \\
(N)\end{array}$ & $\begin{array}{c}e_{1} \\
(\mathrm{~mm})\end{array}$ & $\begin{array}{c}e_{2} \\
(\mathrm{~mm})\end{array}$ & $\begin{array}{c}F_{2} \\
(N)\end{array}$ & $\begin{array}{c}f_{\mathrm{wi}} \\
\left(\mathrm{N} / \mathrm{mm}^{2}\right)\end{array}$ & $\begin{array}{c}\text { Type of collapse } \\
\text { UNI EN 1052-5 }\end{array}$ \\
\hline 1.1 & 1000 & 1100 & 300 & 365 & 0.30 & $\mathrm{~A} 4$ \\
1.2 & 700 & 1100 & 300 & 365 & 0.21 & $\mathrm{~A} 4$ \\
1.3 & 1100 & 1100 & 300 & 365 & 0.33 & $\mathrm{~A} 4$ \\
1.4 & 710 & 1100 & 300 & 365 & 0.22 & $\mathrm{~A} 4$ \\
1.5 & 400 & 1100 & 300 & 365 & 0.13 & $\mathrm{~A} 4$ \\
2.1 & 800 & 1100 & 300 & 365 & 0.24 & $\mathrm{~A} 4$ \\
2.2 & 840 & 1100 & 300 & 365 & 0.25 & $\mathrm{~A} 4$ \\
2.3 & 670 & 1100 & 300 & 365 & 0.20 & $\mathrm{~A} 4$ \\
2.4 & 615 & 1100 & 300 & 365 & 0.19 & $\mathrm{~A} 4$ \\
2.5 & 865 & 1100 & 300 & 365 & 0.26 & $\mathrm{~A} 4$ \\
\hline
\end{tabular}

$f_{\text {wi }}$ : adhesion strength of the single specimen; $f_{\text {wmean }}$ : mean adhesion strength; $f_{\mathrm{wk}}$ : characteristic adhesion strength.

and arranged into 3 groups of 10 each, one made with "ordinary" joints (maximum thickness of $5 \mathrm{~mm}$ ), one with "thin" joints (maximum thickness of $3 \mathrm{~mm}$ ), and one with "super-thin" joints (maximum thickness of $1.5 \mathrm{~mm}$ ). The Module FV "MVI350" type brick blocks have dimensions $35 \times 24 \times 24 \mathrm{~cm}$ and percentage of holes ranging between $45 \%$ and $55 \%$, with thin septa. All joints were made using M1-mortar. The specimens, perfectly rectified, do not need a "cover" in correspondence of the surfaces in contact with the press plates.
TABle 2: Specimen 2: Gasbeton $63 \times 25 \times 24 \mathrm{~cm}$ and foam for masonry.

\begin{tabular}{lcccccc}
\hline $\begin{array}{l}\text { Test } \\
\text { number }\end{array}$ & $\begin{array}{c}F_{1} \\
(N)\end{array}$ & $\begin{array}{c}e_{1} \\
(\mathrm{~mm})\end{array}$ & $\begin{array}{c}E_{2} \\
(\mathrm{~mm})\end{array}$ & $\begin{array}{c}F_{2} \\
(N)\end{array}$ & $\begin{array}{c}f_{\text {wi }} \\
\left(\mathrm{N} / \mathrm{mm}^{2}\right)\end{array}$ & $\begin{array}{c}\text { Type of collapse } \\
\text { UNI EN 1052-5 }\end{array}$ \\
\hline 1.1 & 1750 & 1100 & 300 & 365 & 0.28 & $\mathrm{~A} 4$ \\
1.2 & 2450 & 1100 & 300 & 365 & 0.47 & $\mathrm{A7}$ \\
1.3 & 2600 & 1100 & 300 & 365 & 0.51 & $\mathrm{~A} 7$ \\
1.4 & 2400 & 1100 & 300 & 365 & 0.45 & $\mathrm{~A} 7$ \\
1.5 & 1950 & 1100 & 300 & 365 & 0.33 & $\mathrm{~A} 7$ \\
2.1 & 2150 & 1100 & 300 & 365 & 0.39 & $\mathrm{~A} 7$ \\
2.2 & 2200 & 1100 & 300 & 365 & 0.40 & $\mathrm{~A} 7$ \\
2.3 & 2600 & 1100 & 300 & 365 & 0.51 & $\mathrm{~A} 7$ \\
2.4 & 2500 & 1100 & 300 & 365 & 0.48 & $\mathrm{~A} 7$ \\
2.5 & 2350 & 1100 & 300 & 365 & 0.44 & $\mathrm{A7}$ \\
\hline
\end{tabular}

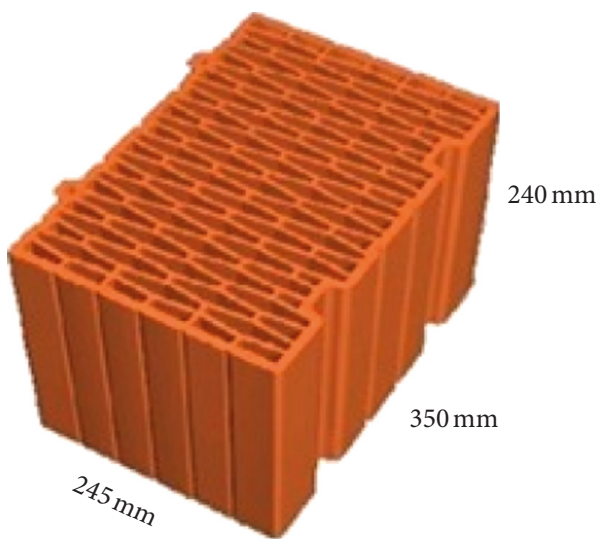

Figure 4: Module FV “MVI350” brick.

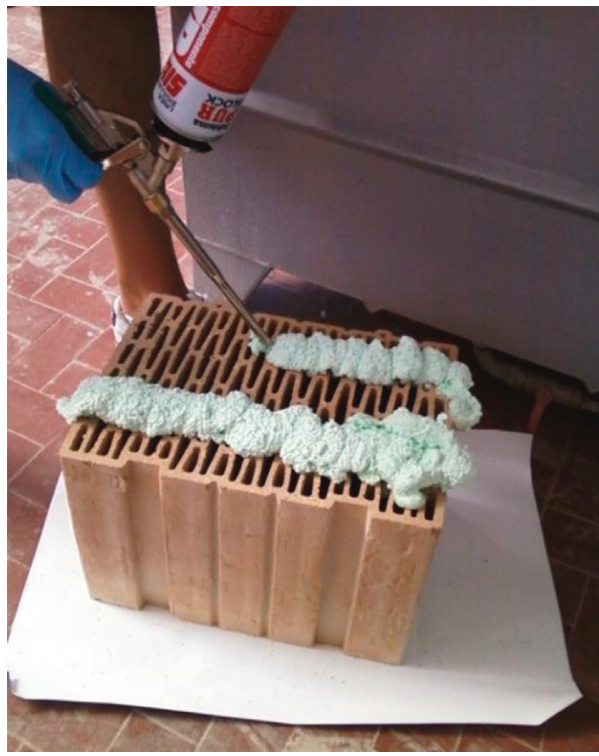

Figure 5: Placement of the foam.

The results are reported in Table 3 , in which a significant dispersion of data, with a standard deviation of about $1.7 \mathrm{~N} / \mathrm{mm}^{2}$, is noticeable. The higher strength was obtained for masonry made with "thin" joints. 
TABLE 3: Values of the ultimate load and compressive strength for different joints and mortar.

\begin{tabular}{lcccccc}
\hline Specimens & $\begin{array}{c}\text { M1-mortar } \\
\text { ordinary joint }\end{array}$ & $\begin{array}{c}\text { M1-mortar } \\
\text { thin joint }\end{array}$ & $\begin{array}{c}\text { M1-mortar } \\
\text { super-thin joint }\end{array}$ & $\begin{array}{c}\text { M2-mortar } \\
\text { ordinary joint }\end{array}$ & $\begin{array}{c}\text { M2-mortar } \\
\text { thin joint }\end{array}$ & $\begin{array}{c}\text { M2-mortar } \\
\text { super-thin joint }\end{array}$ \\
\hline Ultimate load $F_{i, \max }(\mathrm{kN})$ & 741.35 & 818.6 & 751.375 & 1098.5 & 1235.625 & 1125.05 \\
Compressive strength $f_{i}\left(\mathrm{~N} / \mathrm{mm}^{2}\right)$ & 8.826 & 9.745 & 8.945 & 13.077 & 14.71 & 13.393 \\
\hline
\end{tabular}

3.2. Block. The compressive strength, measured perpendicularly to the horizontal joints, is derived from the resistance of small specimens of masonry subjected to test up to collapse, according to UNI EN 1052-1:2001 [36]. The specimens are uniformly loaded in compression and the maximum load to collapse, $F_{\max }$, has been recorded. The characteristic nominal strength of a masonry is obtained from the strength of each specimen. Two specimens were loaded, and the force has been recorded by means of a loading cell, obtaining the ultimate compression load $F_{i, \max }$ and the compressive strength $f_{i}$ by assuming

$$
f_{i}=\frac{F_{i, \max }}{A_{i}}
$$

where $A_{i}=350 \mathrm{~mm} \times 240 \mathrm{~mm}=84000 \mathrm{~mm}^{2}$ (area of the loaded transversal section) and $F_{i, \max }$ is the maximum reached load $(\mathrm{kN})$.

Definitely, the two specimens exhibited ultimate compression loads of $F_{i, \max }=430 \mathrm{kN}$ and $480 \mathrm{kN}$, corresponding to the compressive strengths of about $f_{i}=5.714 \mathrm{~N} / \mathrm{mm}^{2}$ and $f_{i}=5.119 \mathrm{~N} / \mathrm{mm}^{2}$, respectively. Thus, the mean values are: $F_{i}$, $\max =455 \mathrm{kN}$ and $f_{i}=5.4165 \mathrm{~N} / \mathrm{mm}^{2}$. Figure 6 shows the failure modes of the specimens consisting of vertical cracking close to the corners of the block.

The plot in Figure 7 shows the different values of the compressive strength in the case of mortar and foam. It is evidenced that the thickness of the joints does not affect M1mortar much, contrary to M2-mortar.

In both tests, the results are lower than those obtained utilizing the mortar; taking as reference the higher result obtained for the sample made with M2-mortar with thin joints, it is possible to notice a reduction of about $67 \%$ with respect to the mean value obtained for the specimens realized with foam.

3.3. Masonry (Adhesion). In the present section, the purpose of the test is the evaluation of the capacity of a masonry in resisting against the actions that impose shear stresses such as the laboratory slide strength of the foam-brick joints. The test consists in placing a masonry sample under a proper equipment capable of stressing the foam joint between two blocks, with a controlled increasing load up to failure. The tests were carried out on three brick blocks Module FV "MVI350" type with dimensions $35 \times 24.5 \times 24 \mathrm{~cm}$ (length, width, and height, respectively). The percentage of holes was $45 \%<F \leq 55 \%$. The blocks were jointed with polyurethane foam by running two parallel curbs of about $3 \mathrm{~cm}$ thick each, positioned at a distance of about $5 \mathrm{~cm}$ from the longitudinal edge of the block.

The first specimen was placed in between two plates of dimensions $30 \times 30 \times 3 \mathrm{~cm}$, leaving the central block free to slide. The vertical displacement of the block with respect to the adjacent blocks was measured by four displacement

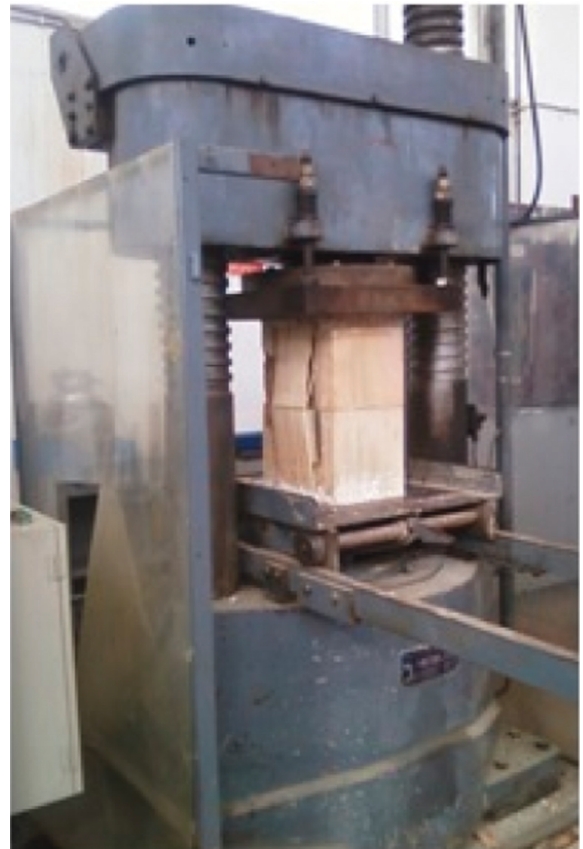

(a)

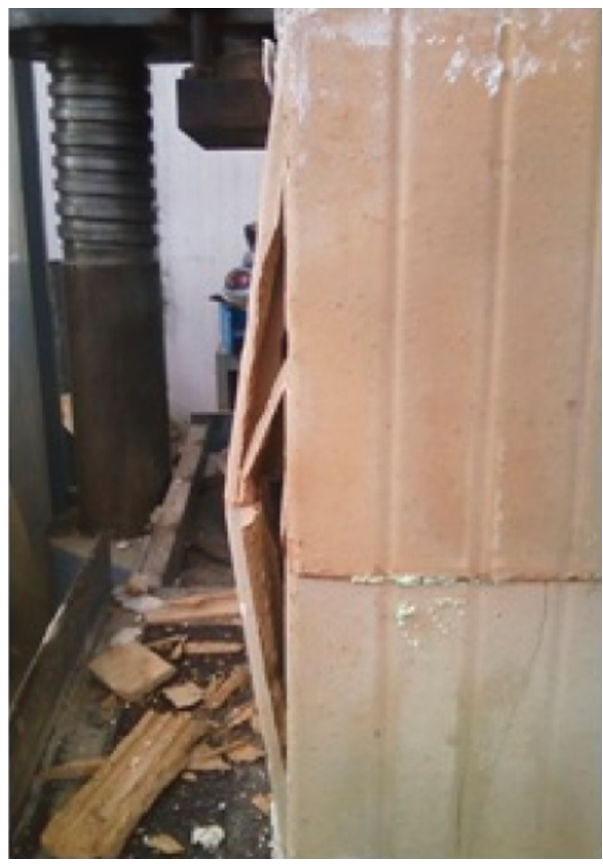

(b)

FIgURE 6: Details of the failure of the block in pure compression test.

transducers positioned on the right and left sides of the sample (Figures $8(\mathrm{a})$ and $8(\mathrm{~b})$ ). The load was applied by a hydraulic jack piston through the load cell connected to the 


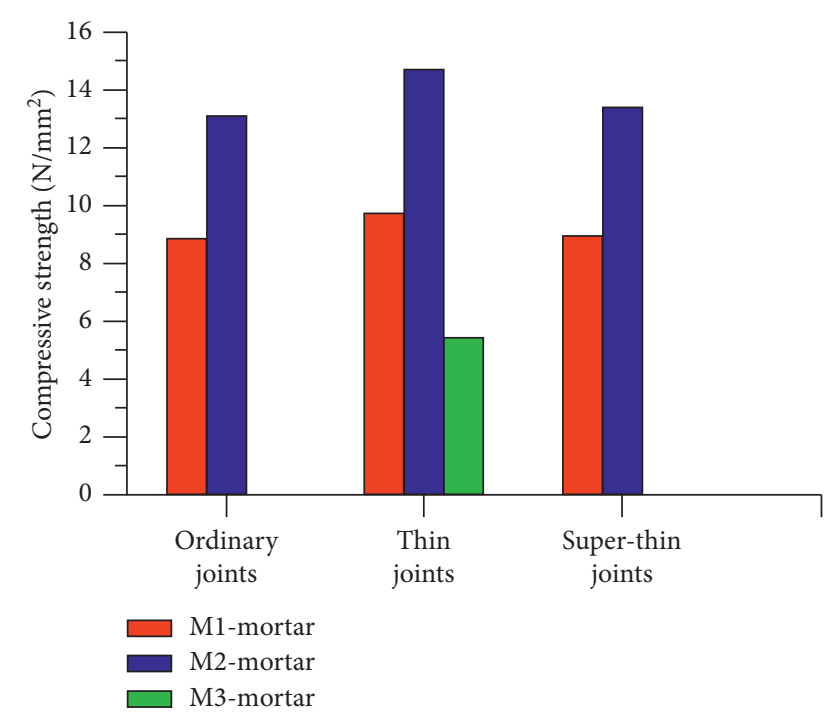

FIGURE 7: Values of the compressive strength as function of the bonding material and the joints.

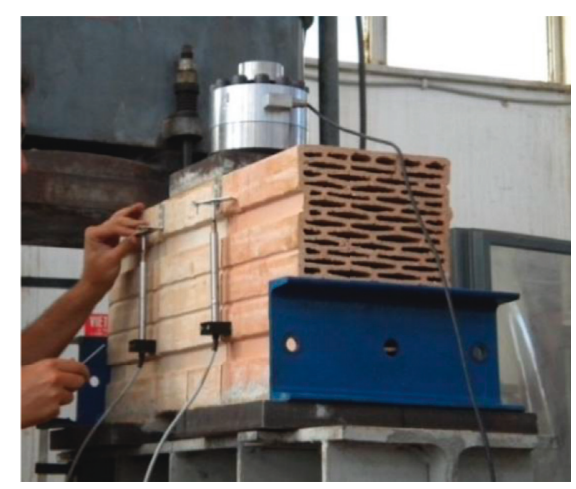

(a)

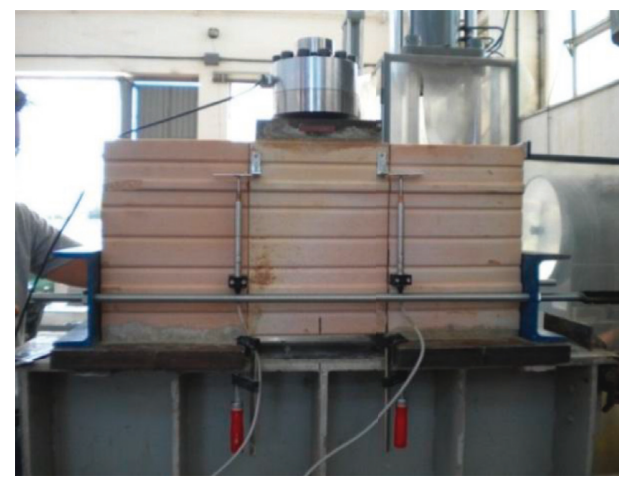

(b)

FIgURE 8: Details of the test setup: (a) positioning of the transducers for measurements; (b) specimen ready for the test.

computer and positioned on the central block by means of a $22 \times 22 \times 3.5 \mathrm{~cm}$ steel plate.

Two external $16 \mathrm{~cm}$ diameter bars have to maintain the position of the sample, thus simulating the contiguity of the blocks in a wall (there was no precompression or presence of stresses normal to the direction of the holes of the bars

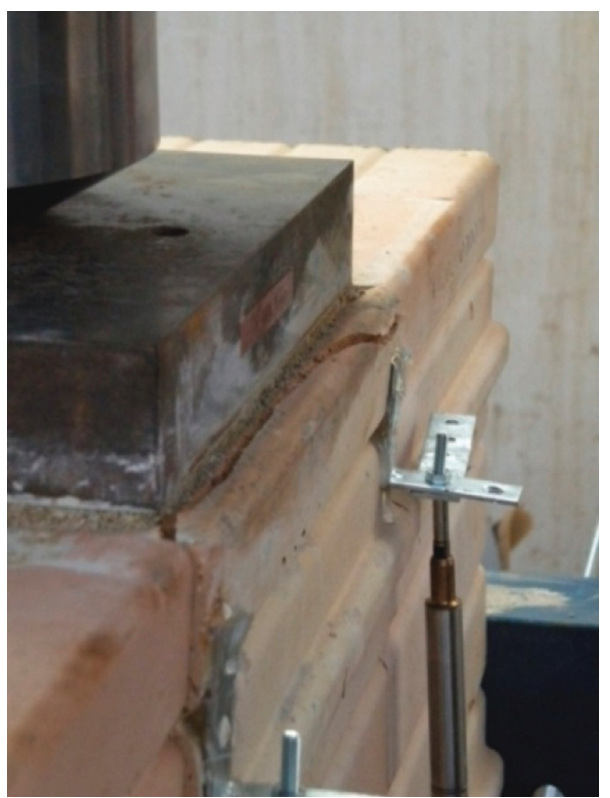

Figure 9: First specimen failure under the maximum load.

because the bolts have been tightened). The specimen was subjected to a crescent load up to the failure; the failure appeared in the central block under the loading plate (Figure 9). The maximum recorded load was $17.25 \mathrm{kN}$.

The displacements (Def) measured at the four transducers were as follows:
(i) Def1 $=0.369 \mathrm{~mm}$
(ii) $\mathrm{Def} 2=0.181 \mathrm{~mm}$
(iii) Def3 $=0.244 \mathrm{~mm}$
(iv) Def $4=0.493 \mathrm{~mm}$.

During the unloading phase, an increment of the displacements in nodes 1 and 2 towards the bottom was noticed, while a displacement towards the top occurred in nodes 3 and 4 (Figures 10(a) and 10(b)). However, the displacements obtained during the unloading phase were influenced by the collapse of the block and therefore irrelevant for the foam-block adherence test.

The load-displacement plots show an almost linear trend of displacements depending on the specimen's load up to failure (Figure 11).

The failure occurred in the central block (second specimen) under the loading plate is reported in Figure 12. The maximum recorded load was $14.80 \mathrm{kN}$, while the displacement recordings in the four transducers were as follows:
(i) $\operatorname{Def1}=0.237 \mathrm{~mm}$
(ii) $\mathrm{Def} 2=0.227 \mathrm{~mm}$
(iii) Def3 $=0.206 \mathrm{~mm}$
(iv) Def $4=0.177 \mathrm{~mm}$.

It is possible to notice that in this case, the displacements have more uniform values but a lower maximum failure load.

Similarly to the previous test, the specimen was then subjected to an unloading phase. From the plot in Figure 13, 


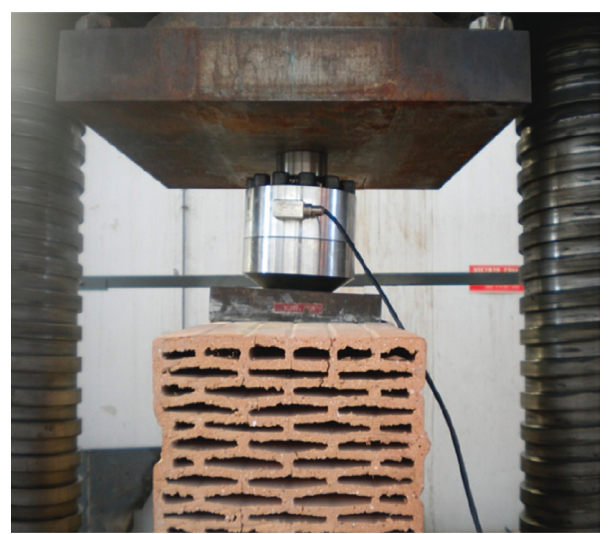

(a)

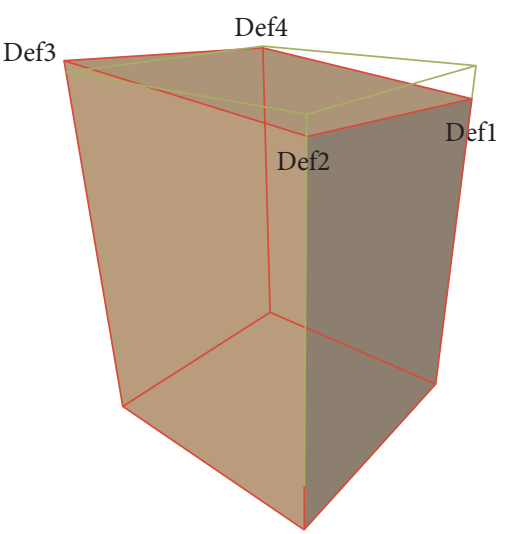

(b)

FIGURE 10: Details of the test on triplets: (a) specimen after the unloading; (b) 3D visual of the displacement at the end of the unloading tests.

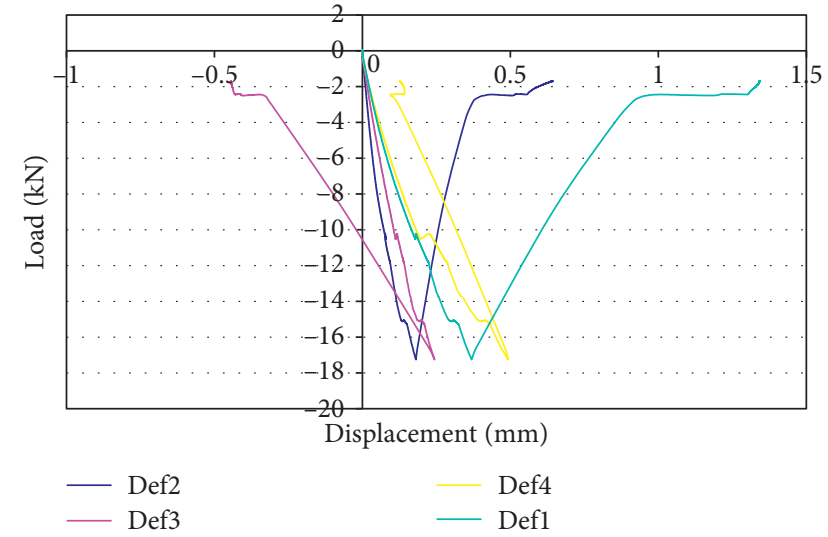

FIgURE 11: Load-displacement plot of the first triplet test.

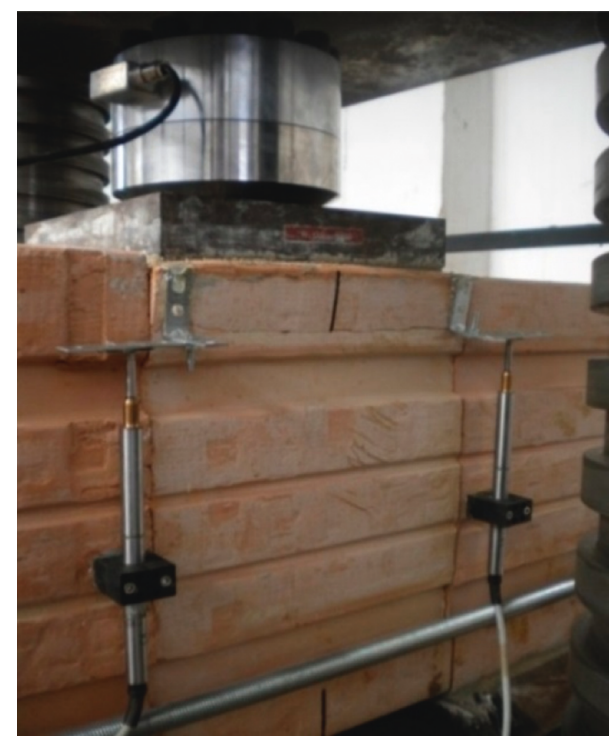

FIGURE 12: Second specimen failure under the maximum load.

the trend of the displacements as function of the applied load can be observed. Also, in this case, it is possible to notice a linear trend of the displacements up to failure. By comparing

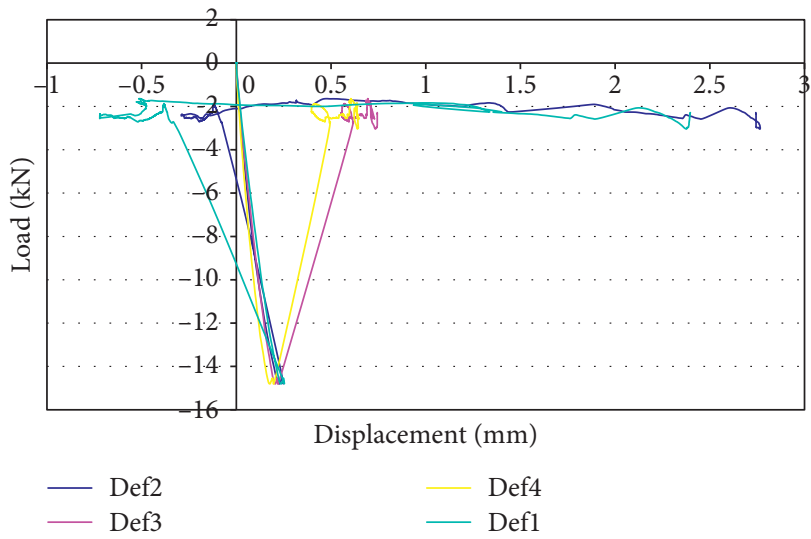

FIGURE 13: Load-displacement plot of the second triplet test.

the results obtained for the first specimen, the failure is obtained for lower values of the load, and the peak displacement is the same for all the transducers.

In addition, the initial characteristic shear strength without normal stresses has been experimentally determined according to [37]. The characteristic strength $f_{\mathrm{vk} 0}$ has been deduced from the mean strength $f_{\mathrm{vm}}$, obtained from the test results, by means of the following expression:

$$
f_{\mathrm{vk} 0}=0.7 f_{\mathrm{vm}} \text {. }
$$

In the present case, the mean strength on the two tests is equal to

$$
f_{\mathrm{vm}}=0.09535 \mathrm{~N} / \mathrm{mm}^{2} \text {, }
$$

and the experimental characteristic shear strength is

$$
f_{\mathrm{vk} 0}=0.7 f_{\mathrm{vm}}=0.066745 \mathrm{~N} / \mathrm{mm}^{2} \text {. }
$$

The detailed results (6 specimens) are shown in Table 4, by reporting the geometrical dimensions of the six specimens, the failure loads, and the shear strength reached during the tests.

All samples showed a shear failure in the element/mortar connecting area on one side or divided between the two sides 
TABLE 4: Results of the tests on the six specimens.

\begin{tabular}{|c|c|c|c|c|c|c|}
\hline \multirow{2}{*}{ Specimen } & \multicolumn{3}{|c|}{$\begin{array}{l}\text { Specimen's } \\
\text { dimensions }\end{array}$} & \multirow{2}{*}{$\begin{array}{c}\text { Area of the } \\
\text { transversal } \\
\text { section } A_{i} \\
\left(\mathrm{~mm}^{2}\right)\end{array}$} & \multirow{2}{*}{$\begin{array}{c}\text { Failure } \\
\text { load } \\
F_{i, \max } \\
(N)\end{array}$} & \multirow{2}{*}{$\begin{array}{c}\text { Shear } \\
\text { strength } \\
f_{\mathrm{v} 0 \mathrm{i}} \\
\left(\mathrm{N} / \mathrm{mm}^{2}\right)\end{array}$} \\
\hline & $\begin{array}{c}L \\
(\mathrm{~mm})\end{array}$ & $\begin{array}{c}l \\
(\mathrm{~mm})\end{array}$ & $\begin{array}{c}h \\
(\mathrm{~mm})\end{array}$ & & & \\
\hline 1 & 234.0 & 373.0 & 667. & & 55500 & 0.32 \\
\hline 2 & 2 & 373 & 667 & & & 0.3 \\
\hline 3 & 234.5 & 373.5 & 667 & & 578 & 0.33 \\
\hline 4 & 2 & 37 & 66 & & 458 & 0.26 \\
\hline 5 & 234.0 & 373.5 & 667 & & 506 & 0.29 \\
\hline 6 & 234.0 & 373.0 & 667.0 & 872 & 54900 & 0.31 \\
\hline \multicolumn{5}{|c|}{ Total number of samples } & $\mathrm{n}$ & 6 \\
\hline \multicolumn{5}{|c|}{ Average shear strength $f_{\mathrm{vm} 0}$} & $\mathrm{~N} / \mathrm{mm}$ & 0.31 \\
\hline \multicolumn{5}{|c|}{ Characteristic value $f_{\mathrm{vk} 0}=0.7 f_{\mathrm{vm} 0}$} & $\mathrm{~N} / \mathrm{mm}^{2}$ & 0.22 \\
\hline
\end{tabular}

of the element (Figure 14) according to A1 type of failure (Appendix A of UNI EN 1052-3) [37].

After that, a total of 6 masonry samples have been realized assembling 3 brick blocks M3-mortar $38 \times 25 \times 21.9 \mathrm{~cm}$, laid down in the direction of the vertical holes and joined together with M3-mortar with $0.1-0.2 \mathrm{~cm}$ thick continuous joints (Figure 15). The manufacturing of the specimens is of type I according to [37]. The test samples were imposed in a standard condition habitat ageing for at least 28 days at $20^{\circ} \mathrm{C}$ and relative humidity of $70 \%$ before the test. The shear strength test was conducted by applying the load according to type B procedure with zero prestressing (section 8.2 of EN 1052-3: 2007) [37].

The specimens were positioned in the testing machine following the prescriptions in section 8.1 of UNI EN 1052-3 [37] smoothing with the mortar the bearing surfaces at the fix connections (Figure 16).

Moreover, the loading speed was set in the range 0.1$0.4 \mathrm{~N} / \mathrm{mm}^{2}$ per minute. Again, the shear strength was obtained according to $f_{\text {vio }}=F_{i, \max } / 2 A_{i}$, while the characteristic shear strength was obtained from $f_{\mathrm{vk} 0}=0.7 f_{\mathrm{vm} 0}$.

The detected dispersions are related to the type of brick used in the experimental tests. In fact, the hollow bricks would not be the most suitable for this type of test because the brick's holes can be filled more or less by the foam in dependence of the thixotropy characteristics, the dimension of the holes, and the pressure exerted on the joints, which decreases passing from the lower joints of the wall to the top ones. With regard to the laboratory tests, both in the case of vertical compression and in the sliding of triplets, strength values lower with the foam than with the mortars have been obtained. Tables 5 and 6 show the results of the tests for the different cases.

The average value of the characteristic shear strength for the first two specimens is equal to $0.095 \mathrm{~N} / \mathrm{mm}^{2}$, lower than the value obtained for the specimens with mortar $\left(0.263 \mathrm{~N} / \mathrm{mm}^{2}\right)$.

3.4. Masonry (Shear). Substrates of rectified brick blocks must be sufficiently resistant, solid and smooth, clean and healthy, free from oils and grease, dust, loose and dirty material, and without any trace of old paint surfaces. They must also be sufficiently cured and free of significant shrinkage.

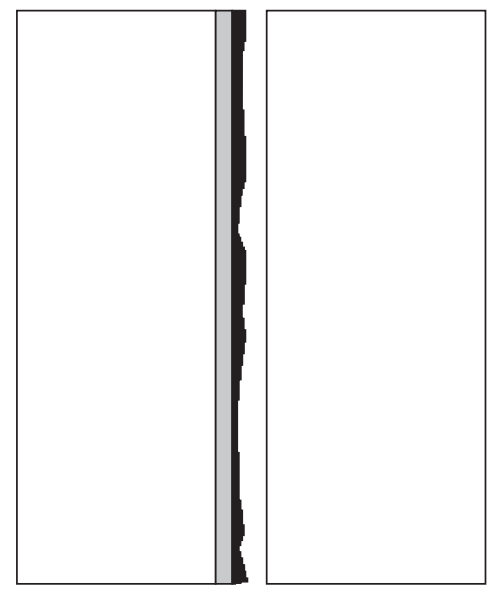

(a)

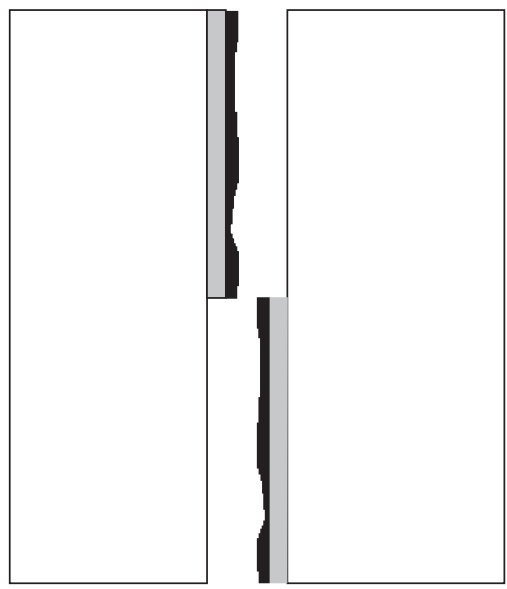

(b)

FIGURE 14: Shear failure in the element/mortar interface: (a) on one surface; (b) divided between two surfaces of the element.

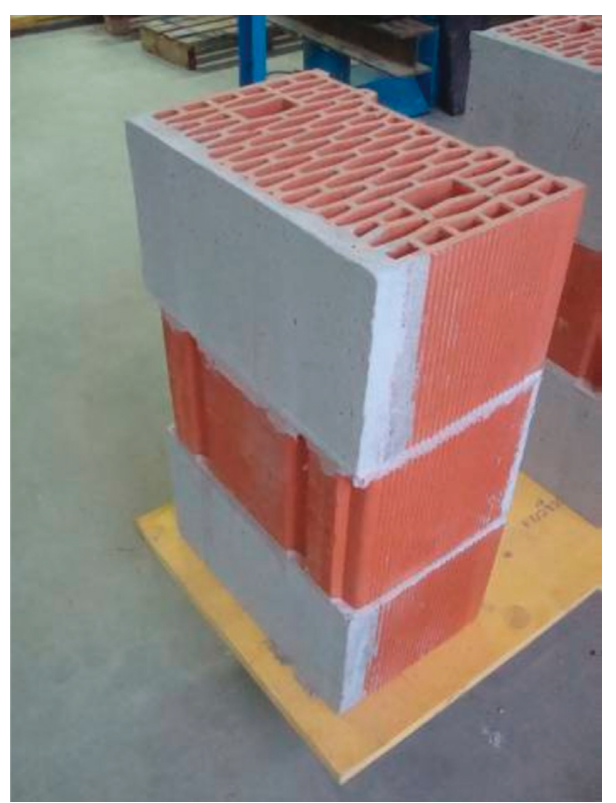

FIGURE 15: Specimen constituted by three blocks. 


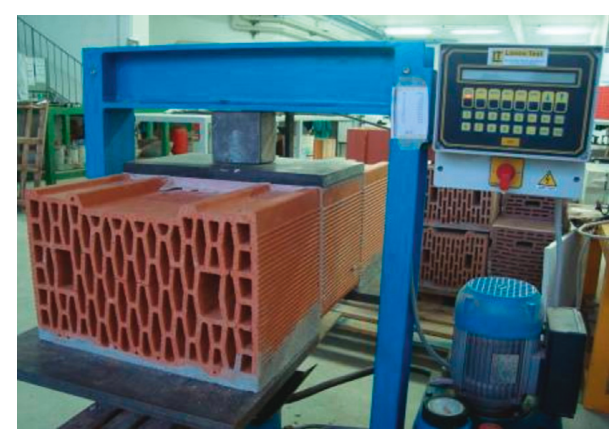

FIgURE 16: Positioning in the testing machine.

The foam is placed in curbs about $3 \mathrm{~cm}$ thick (Figure 17); in the case of rectified masonry blocks unperforated (cellular concrete, aerated, and/or autoclaved), the thickness of the foam curbs is reduced to $1.5 \mathrm{~cm}$ to avoid the possible phenomena of translational displacements and/or slight elevations of the block itself. Accompanying sheet reports useful date regarding the foam as listed down in Table 7.

The system was fast and easy to apply and allowed a reduction of the waiting time because the masonry was not wetted by the foam (contrary to what happens with mortar) and the higher speed of drying of the polyurethane foam itself. These elements lead to the final advantage to allow to continue with the subsequent processing steps in very short times.

The complete curing of the foam is achieved in a few hours after application. The final ageing and use takes place after 3-4 days approximately. In such a short time, it will already be possible to obtain the maximum performance of the wall. The thin-bed mortar was also characterized by a bonding with elastic characteristics, with all the consequent advantages. Consequently, the shear strength of the specimens is obtained from the following expression [38]:

$$
f_{\mathrm{v} 0 \mathrm{i}}=\frac{F_{i, \max }}{2 A_{i}},
$$

where $F_{i, \max }$ is the maximum shear force $(N)$ and $A_{i}$ is the transversal section of a specimen parallel to the horizontal joints $\left(\mathrm{mm}^{2}\right)$. Two specimens have been prepared, one with foam and one with mortar.

The main results are listed as follows:

(i) Specimen 1: $37 \times 25 \times 23.5 \mathrm{~cm}$ wall made of rectified bricks and foam for masonry. Mean value of the initial shear strength: $f_{\mathrm{v} 0 \mathrm{~m}}=0.17 \mathrm{~N} / \mathrm{mm}^{2}$.

(ii) Specimen 2: $37 \times 25 \times 23.5 \mathrm{~cm}$ wall made of rectified bricks and mortar for masonry.

Mean value of the initial shear strength: $f_{\mathrm{v} 0 \mathrm{~m}}=$ $0.16 \mathrm{~N} / \mathrm{mm}^{2}$.

The initial characteristic shear strength $f_{\mathrm{v} 0 \mathrm{k}}$ is obtained as follows:

$$
f_{v 0 k}=0.8 f_{v 0 m}=0.136 \mathrm{~N} / \mathrm{mm}^{2} .
$$

The mechanical shear strength of the masonry wall made with hollow bricks and one with polyurethane foam and one with M1-mortar has been investigated and then compared in diagonal compressive strength according to [38].

Specifically, seven wall specimens of nominal dimensions $1116 \times 1245 \mathrm{~mm}$ and $240 \mathrm{~mm}$ thick have been realized for diagonal compression tests. In particular, the following tests have been carried out:

(i) 4 diagonal compression tests on walls made of hollow elements and mortar;

(ii) 3 diagonal compression tests on walls made of hollow elements and bedding foam.

Each sample was placed under a test setup properly designed and realized. It was made up of two steel caps; the caps were connected to each other by hauling systems consisting of chains and hydraulic jacks (Figure 18). The result of this imposed stress state is therefore a concentrated $45^{\circ}$ oriented force with respect to the sides of the sample and central with respect to the section of the specimen. The wall specimen was instrumented with pressure gauges and strain bases placed along the diagonals. The mean shear strength is obtained from the following analytical expression:

$$
S_{\mathrm{s}}=\frac{0.707 P}{A_{\mathrm{n}}}
$$

where $S_{\mathrm{s}}$ is the mean shear strength along the sliding surface; $P$ is the applied force along $45^{\circ}$; and $A_{\mathrm{n}}$ is the net area of the specimen, that is $(w+h) t / 2$, in which $w, h$, and $t$ are the dimensions of the specimen.

The results are shown in Table 8 for the specimens made with mortar and in Table 9 for the specimens made with foam. From the tables, the dissipative effect that the foams are able to provide to the masonry is clearly evidenced. In fact, a significantly higher value of the maximum deformation $\varepsilon_{\max }$ due to shear and energy dissipation $G_{\mathrm{V}}$ was reached.

It is possible to notice that in the second series of specimens, made with foam, the collapse was reached for higher values of the load, while deformations are comparable, except for 1-FOAM specimen.

\section{Conclusions and Future Developments}

The present study showed that a masonry element introduces some difficulties caused by the great variety of possible combinations of elements and binder and of the consequent difficulty in generalizing the information obtained on a limited number of combinations.

The phenomena of cracking and damage in the masonry evidence the need of the nonlinear analyses, carried out frequently in the case of materials not resistant to tensile forces. The results of the conducted experimental campaign were as follows:

(i) In the case of diagonal compression test for masonry with foam, the collapse is reached for higher values of the load, while deformations are comparable to the masonry with M2-mortar. 
TABLE 5: Results of vertical compression tests.

\begin{tabular}{lcccc}
\hline & & Test of vertical compression on blocks \\
& Brick & Binder & $\begin{array}{c}\text { Maximum } \\
\text { load }(\mathrm{KN})\end{array}$ & $\begin{array}{c}\text { Compressive strength } \\
\left(\mathrm{N} / \mathrm{mm}^{2}\right)\end{array}$ \\
\hline Specimen 1 (thin joint) & Module FV “MVI350" $(35 \times 25 \times 24.5 \mathrm{~cm})$ & Polyurethane foam & 480 & 5.714 \\
Specimen 2 (thin joint) & Module FV "MVI350" $(35 \times 25 \times 24.5 \mathrm{~cm})$ & Polyurethane foam & 430 & 5.119 \\
Specimen 3 (ordinary joint) & Iper $(30 \times 24 \times 24 \mathrm{~cm})$ & M1-mortar & 741.35 & 8.513 \\
Specimen 4 (thin joint) & Iper $(30 \times 24 \times 24 \mathrm{~cm})$ & M1-mortar & 818.6 & 9.40 \\
Specimen 5 (super-thin joint) & Iper $(30 \times 24 \times 24 \mathrm{~cm})$ & M1-mortar & 751.37 & 8.629 \\
Specimen 6 (ordinary joint) & Iper $(30 \times 24 \times 24 \mathrm{~cm})$ & M2-mortar & 1098.5 & 12.615 \\
Specimen 7 (thin joint) & Iper $(30 \times 24 \times 24 \mathrm{~cm})$ & M2-mortar & 1235.62 & 14.19 \\
Specimen 8 (Giunto Supersottile) & Iper $(30 \times 24 \times 24 \mathrm{~cm})$ & M2-mortar & 1125.05 & 12.92 \\
\hline
\end{tabular}

TABLE 6: Results of the sliding on triplet tests.

\begin{tabular}{lcccc}
\hline & & Test of sliding on triplets & \\
& Brick & Binder & Maximum load $(\mathrm{KN})$ & Shear strength $\left(\mathrm{N} / \mathrm{mm}^{2}\right)$ \\
\hline Specimen 1 & Module FV “MVI350” $(35 \times 25 \times 24.5 \mathrm{~cm})$ & Polyurethane foam & 17.236 & 0.102 \\
Specimen 2 & Module FV “MVI350" $(35 \times 25 \times 24.5 \mathrm{~cm})$ & Polyurethane foam & 14.802 & 0.0881 \\
Specimen 3 & Porotherm Bio Plan $(38 \times 25 \times 21.9 \mathrm{~cm})$ & M3-mortar & 55.5 & 0.274 \\
Specimen 4 & Porotherm Bio Plan $(38 \times 25 \times 21.9 \mathrm{~cm})$ & M3-mortar & 58.1 & 0.283 \\
Specimen 5 & Porotherm Bio Plan $(38 \times 25 \times 21.9 \mathrm{~cm})$ & M3-mortar & 57.8 & 0.283 \\
Specimen 6 & Porotherm Bio Plan $(38 \times 25 \times 21.9 \mathrm{~cm})$ & M3-mortar & 45.8 & 0.223 \\
Specimen 7 & Porotherm Bio Plan $(38 \times 25 \times 21.9 \mathrm{~cm})$ & M3-mortar & 50.6 & 0.248 \\
Specimen 8 & Porotherm Bio Plan $(38 \times 25 \times 21.9 \mathrm{~cm})$ & M3-mortar & 54.9 & 0.265 \\
\hline
\end{tabular}

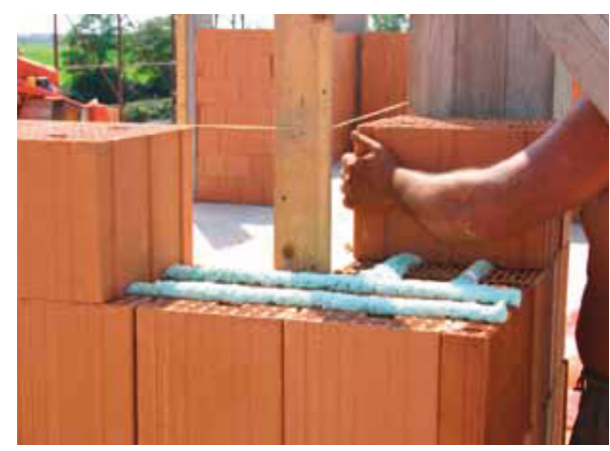

FIgURE 17: Example of foam placement on the brick.

(ii) The higher compressive strengths of the tested specimens with M1-mortar and M2-mortar are obtained for masonry made with "thin" joints.

(iii) The compressive strength of the masonry specimens with foam joints is lower than those obtained utilizing the mortar.

(iv) Foam joints were able to improve the ductility and the energy dissipation of the masonry, which is a desirable capacity in seismic prone areas.

In conclusion, the following observations are proposed:

(i) All specimens show a failure due to crushing and/or split in the elements.
TABle 7: Technical data of the foam.

\begin{tabular}{lc}
\hline Color & Light green \\
\hline $\begin{array}{l}\text { Exterior temperature during } \\
\text { the application }\end{array}$ & From $-5^{\circ} \mathrm{C}$ to $+40^{\circ} \mathrm{C}$ \\
$\begin{array}{l}\text { Temperature } \\
\text { Action film surface (at } 23^{\circ} \mathrm{C} \text { and }\end{array}$ & From $-40^{\circ} \mathrm{C}$ to $+120^{\circ} \mathrm{C}$ \\
$50 \%$ of RU) & $7-10 \mathrm{~min}$ \\
$\begin{array}{l}\text { Traceability }(20 \mathrm{~mm} \text { diameter } \\
\text { curb at } 23^{\circ} \mathrm{C} \text { and } 50 \% \text { of UR) }\end{array}$ & $30-40 \mathrm{~min}$ \\
$\begin{array}{l}\text { Bulk density (after opposed expansion) } \\
\text { Dimensional variation (at } 23^{\circ} \mathrm{C}\end{array}$ & $13-18 \mathrm{~kg} / \mathrm{m}^{3}$ \\
and $50 \%$ of UR) & $<3 \%$ \\
$\begin{array}{l}\text { Fire behavior } \\
\text { UV resistance }\end{array}$ & $\mathrm{B} 2$ \\
Impermeability/sealing pressure & Scarce, tends to yellow \\
\hline
\end{tabular}

(ii) The blocks utilized in this study due to their geometry are not the most suitable for this type of testing, since the holes are insufficient to ensure appropriate stress distributions. However, these blocks meet the requirements in terms of insulation and thermal transmittance.

Then, the recorded shear strength values cannot be considered explanatory of the foam-brick adhesion phenomenon; they still apply the following properties:

(i) The excellent adhesion on different types of supports 


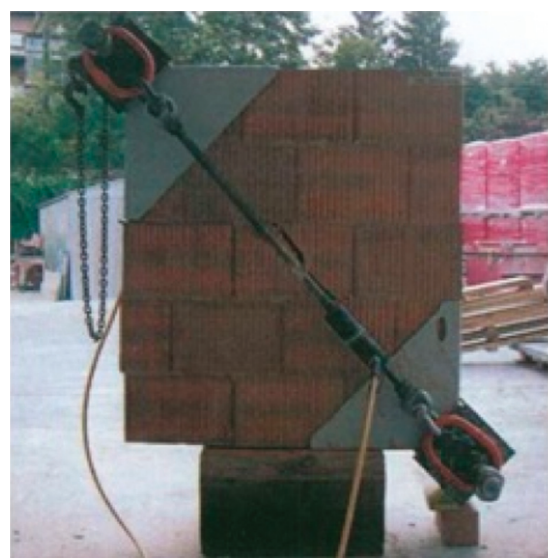

(a)

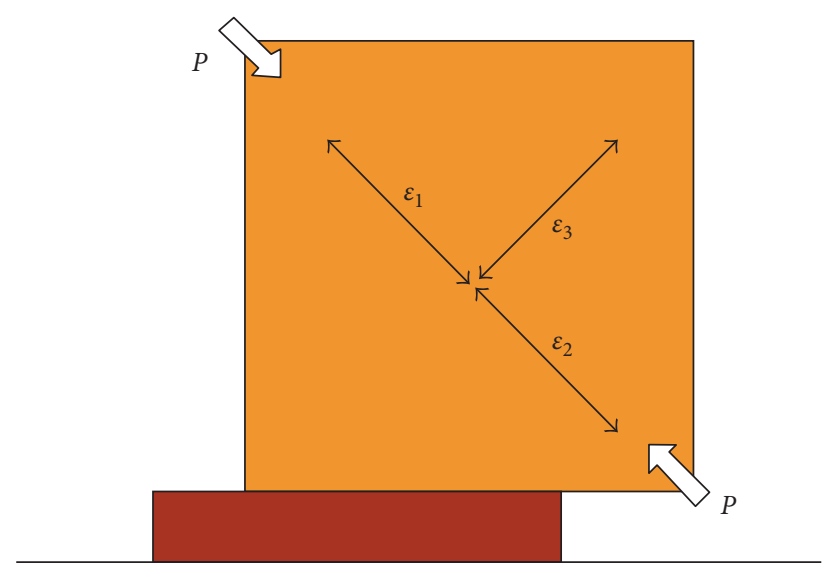

(b)

FIgURE 18: Details of the diagonal compression test (a) and relative test setup (b).

TABLE 8: Mean shear strength in case of diagonal compression test for masonry with mortar.

\begin{tabular}{lcccccc}
\hline Test & $A_{\mathrm{n}}\left(\mathrm{mm}^{2}\right)$ & $P(N)$ & $S_{\mathrm{s}}\left(\mathrm{N} / \mathrm{mm}^{2}\right)$ & $\varepsilon_{\max }(\%)$ & $G_{\mathrm{V}}(\mathrm{MPa})$ & Type of collapse \\
\hline 1-MORTAR & 283320 & 80000 & 0.20 & 0.13 & 0.017 & $\begin{array}{c}\text { Collapse for tensile cracking along the compressed } \\
\text { diagonal. }\end{array}$ \\
\hline 3-MORTAR & 283320 & 85000 & 0.21 & 0.14 & 0.018 & $\begin{array}{c}\text { Collapse for tensile cracking along the compressed } \\
\text { diagonal. }\end{array}$ \\
\hline 4-MORTAR & 283320 & 70000 & 0.17 & 0.07 & 0.006 & $\begin{array}{c}\text { Collapse for tensile cracking along the compressed } \\
\text { diagonal. }\end{array}$ \\
\hline
\end{tabular}

TABLE 9: Mean shear strength in case of diagonal compression test for masonry with foam.

\begin{tabular}{|c|c|c|c|c|c|c|}
\hline Test & $A_{\mathrm{n}}\left(\mathrm{mm}^{2}\right)$ & $P(N)$ & $S_{\mathrm{s}}\left(\mathrm{N} / \mathrm{mm}^{2}\right)$ & $\varepsilon_{\max }(\%)$ & $G_{\mathrm{V}}(\mathrm{MPa})$ & Type of collapse \\
\hline 1-FOAM & 283320 & 70000 & 0.17 & 0.23 & 0.026 & $\begin{array}{l}\text { Collapse for tensile cracking along the compressed } \\
\text { diagonal and substantial collapse of the head brick in } \\
\text { correspondence of the loading areas. }\end{array}$ \\
\hline 2-FOAM & 283320 & 110000 & 0.27 & 0.14 & 0.025 & $\begin{array}{l}\text { Collapse for tensile cracking along the compressed } \\
\text { diagonal. }\end{array}$ \\
\hline 3-FOAM & 283320 & 110000 & 0.27 & 0.24 & 0.045 & $\begin{array}{l}\text { Collapse for tensile cracking along the compressed } \\
\text { diagonal and corresponding to the loading areas and } \\
\text { for shear sliding of the center of the specimen. }\end{array}$ \\
\hline
\end{tabular}

(ii) The high impermeability

(iii) The good chemical resistance

(iv) The extreme speed of installation with a reduction of up to $50 \%$ of the time compared to the use of thinbed mortar

(v) The high cleanliness and the almost total reduction of tools

(vi) The sharp reduction in processing costs and the total costs.

In conclusion, the presented methodology can therefore be considered valid and can be used for such studies, considering an elastic-plastic behavior of the masonry, closer to its actual behavior.

\section{Data Availability}

The data used to support the findings of this study are available from the corresponding author upon request.

\section{Conflicts of Interest}

The authors declare that they have no conflicts of interest.

\section{References}

[1] A. N. Fried, J. J. Roberts, M. C. Limbachiya, and A. Ahmed, "Thin joint masonry in the UK," Masonry International Journal of British Masonry Society, pp. 85-87, 2005. 
[2] A. N. Fried, J. Ali, O. J. Kanyeto, and J. J. Roberts, "The properties of wet and dry thin layer mortar," in Proceedings of 7th International Masonry Conference, pp. 234-243, London, UK, October 2006.

[3] A. Jabbar, A. Fried, O. J. Kanyeto, and J. J. Roberts, "Compressive strength of thin joint solid dense concrete blockwork," in Proceedings of 7th International Masonry Conference, London, UK, October 2006.

[4] M. R. Valluzzi, F. Da Porto, and C. Modena, "Mechanical behaviour of masonry made of flat blocks and thin mortar joints," in Proceedings of 6th International Masonry Conference, pp. 503-511, London, UK, November 2002.

[5] O. J. Kanyeto and A. Fried, "Flexural behaviour of thin joint concrete blockwork: Experimental results," Construction and Building Materials, vol. 25, no. 8, pp. 3639-3647, 2011.

[6] N. Walliman, B. Baiche, and R. Ogden, "Thin-joint glued brickwork: Building in the British context," Construction and Building Materials, vol. 22, no. 6, pp. 1081-1092, 2008.

[7] D. Foti, "Shape optimization of rectified brick blocks for the improvement of the out-of-plane behavior of masonry," International Journal of Mechanical Sciences, vol. 7, pp. 417-424, 2013, ISSN: 1998-4448.

[8] D. Foti and A. Romanazzi, "Experimental analysis of fiberreinforced mortar for walls in rectified brick blocks Analisi sperimentale di malte fibrorinforzate per pareti in blocchi di laterizio rettificati," $C$ and $C a$, vol. 41, no. 2, pp. 109-118, 2011, ISSN: 0045-6152.

[9] D. Foti and S. Vacca, "Comportamiento mecánico de columnas de hormigón armado reforzadas con mortero reoplástico/mechanical behavior of concrete columns reinforced with rheoplastic mortar," Materiales de Construcción, vol. 63, no. 310, pp. 267-282, 2013.

[10] D. Foti, "Preliminary analysis of concrete reinforced with waste bottles PET fibers," Construction and Building Materials, vol. 25, no. 4, pp. 1906-1915, 2011.

[11] D. Foti, "Use of recycled waste pet bottles fibers for the reinforcement of concrete," Composite Structures, vol. 96, pp. 396-404, 2013.

[12] D. Foti and F. Paparella, "Impact behavior of structural elements in concrete reinforced with PET fibers," Mechanics Research Communications, vol. 57, pp. 57-66, 2014.

[13] D. Foti, "Innovative techniques for concrete reinforcement with polymers," Construction and Building Materials, vol. 112, pp. 202-209, 2016.

[14] P. Medeiros, G. Vasconcelos, P. B. Lourenço, and J. Gouveia, "Numerical modelling of non-confined and confined masonry walls," Construction and Building Materials, vol. 41, pp. 968-976, 2013.

[15] R. Klingner, "Behavior of masonry in the northridge (US) and Tecomán-Colima (Mexico) earthquakes: lessons learned, and changes in US design provisions," Construction and Building Materials, vol. 20, no. 4, pp. 209-219, 2006.

[16] M. Sedlmajera, J. Zach, V. Novak, J. Hroudova, and A. Horsky, "Alternative technology of constructing masonry structures designed for areas with increased seismic activity," Procedia Engineering, vol. 151, pp. 177-182, 2016.

[17] H. Tuwair, M. Hopkins, J. Volz et al., "Evaluation of sandwich panels with various polyurethane foam-cores and ribs," Composites Part B, vol. 79, pp. 262-276, 2015.

[18] A. Shams, A. Stark, F. Hoogen, J. Hegger, and H. Schneider, "Innovative sandwich structures made of high performance concrete and foamed polyurethane," Composite Structures, vol. 121, pp. 271-279, 2015.
[19] G. Zhang, B. Wang, L. Ma, L. Wu, S. Pan, and J. Yang, "Energy absorption and low velocity impact response of polyurethane foam filled pyramidal lattice core sandwich panels," Composite Structures, vol. 108, pp. 304-310, 2014.

[20] A. Manalo, "Structural behaviour of a prefabricated composite wall system made from rigid polyurethane foam and Magnesium Oxide board," Construction and Building Materials, vol. 41, pp. 642-653, 2013.

[21] S. T. Taher, R. Zahari, S. Ataollahi, F. Mustapha, and S. Basri, "A double-cell foam-filled composite block for efficient energy absorption under axial compression," Composite Structures, vol. 89, no. 3, pp. 399-407, 2009.

[22] S. Kishimoto, Q. Wang, Y. Tanaka, and Y. Kagawa, "Compressive mechanical properties of closed-cell aluminum foam-polymer composites," Composites: Part B, vol. 64, pp. 43-49, 2014.

[23] M. Guden, S. Yüksel, A. Tasdemirci, and M. Tanoglu, "Effect of aluminum closed-cell foam filling on the quasi-static axial crush performance of glass fiber reinforced polyester composite and aluminum/composite hybrid tubes," Composite Structures, vol. 81, no. 4, pp. 480-490, 2007.

[24] K. Stöbener and G. Rausch, "Aluminium foam-polymer composites: processing and characteristics," Journal of $M a$ terials Science, vol. 44, no. 6, pp. 1506-1511, 2009.

[25] S. Sharma, N. E. Rayess, and N. Dukhan, "Preliminary NVH characterization of metal foam-polymer interpenetrating phase composites," in Proceedings of ASME International Mechanical Engineering Congress and Exposition, pp. 445451, Lake Buena Vista, FL, USA, November 2009.

[26] S. Gutiérrez-González, J. Gadea, A. Rodríguez, C. Junco, and V. Calderón, "Lightweight plaster materials with enhanced thermal properties made with polyurethane foam wastes," Construction and Building Materials, vol. 28, no. 1, pp. 653658, 2012.

[27] J. A. Thamboo, M. Dhanasekar, and C. Yan, "Effects of joint thickness, adhesion and web shells to the face shell bedded concrete masonry loaded in compression," Australian Journal of Structural Engineering, vol. 14, no. 3, pp. 291-302, 2013.

[28] J. A. Thamboo, M. Dhanasekar, and C. Yan, "Flexural and shear bond characteristics of thin layer polymer cement mortared concrete masonry," Construction and Building Materials, vol. 46, pp. 104-113, 2013.

[29] J. A. Thamboo and M. Dhanasekar, "Characterisation of thin layer polymer cement mortared concrete masonry bond," Construction and Building Materials, vol. 82, pp. 71-80, 2015.

[30] J. A. Thamboo and M. Dhanasekar, "Behaviour of thin layer mortared concrete masonry under combined shear and compression," Australian Journal of Structural Engineering, vol. 17, no. 1, pp. 39-52, 2016.

[31] J. A. Thamboo and M. Dhanasekar, "Nonlinear finite element modelling of high bond thin-layer mortared concrete masonry," International Journal of Masonry Research and Innovation, vol. 1, no. 1, pp. 5-26, 2016.

[32] M. Dhanasekar, J. A. Thamboo, and S. Nazir, "On the in-plane shear response of the high bond strength concrete masonry walls," Materials and Structures, vol. 50, no. 5, p. 214, 2017.

[33] Consiglio Superiore dei Lavori Pubblici, "Approvazione delle nuove norme tecniche per le costruzioni, DM 14.01," Gazzetta Ufficiale della Repubblica Italiana, 2008, in Italian.

[34] Progetto di Ricerca LATEFICIO PUGLIESE SpA-MIUR, Analisi Dell'adesione Malta-Laterizio in Funzione Dello Spessore Dei Giunti e Delle Modalità di Posa, Dipartimento di Ingegneria Civile e Ambientale, Laboratorio Prove Materiali "M. Salvati”, 2008. 
[35] UNI EN 1052-5:2005, Metodi di Prova Per Muratura-Parte 5: Determinazione Della Resistenza All'adesione Con il Metodo a Strappo, Ente Nazionale Italiano di Unificazione, 2005.

[36] UNI EN 772-1:2002, Metodi di Prova Per Elementi di Muratura-Parte 1: Determinazione Della Resistenza a Compressione, Ente Nazionale Italiano di Unificazione, 2002.

[37] UNI EN 1052-3:2007, Metodi di Prova Per Muratura-Parte 3: Determinazione Della Resistenza Iniziale a Taglio, Ente Nazionale Italiano di Unificazione, 2007.

[38] ASTM E519, Standard Test Method for Diagonal Tension (Shear) in Masonry Assemblages, American Society for Testing and Materials, Baltimore, MD, USA, 2010. 


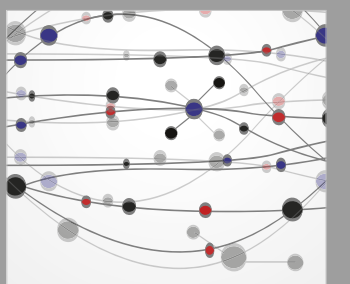

The Scientific World Journal
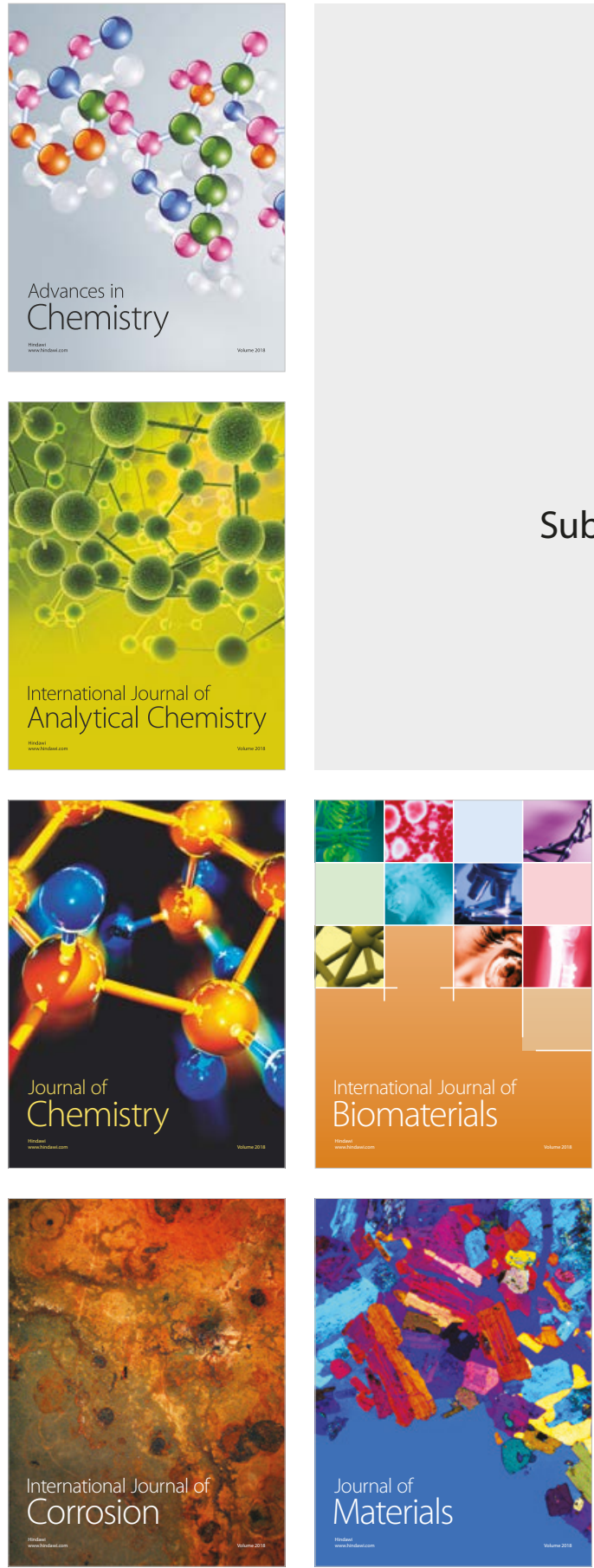

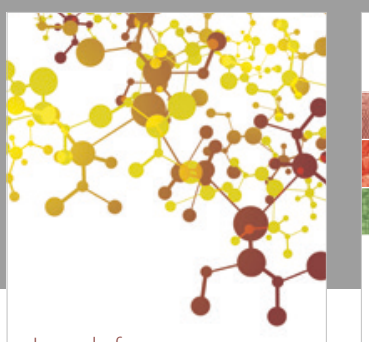

Journal of

Applied Chemistry
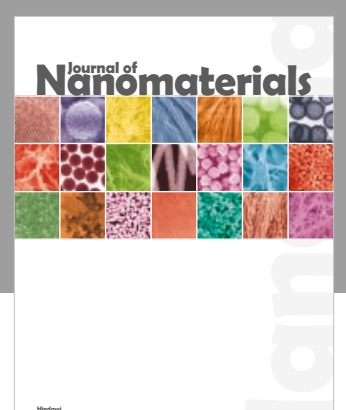

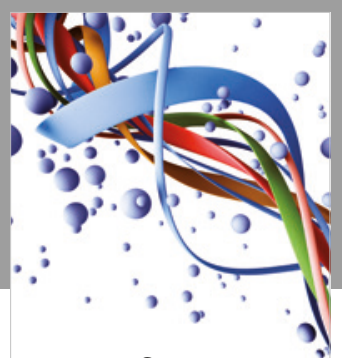

Scientifica

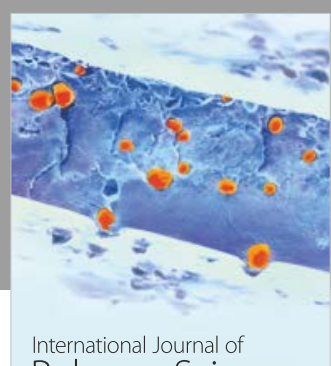

Polymer Science

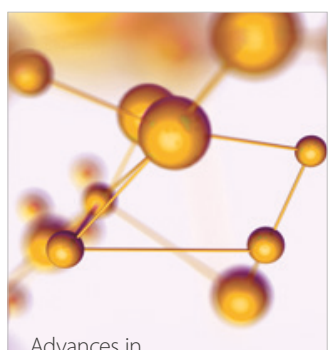

Physical Chemistry
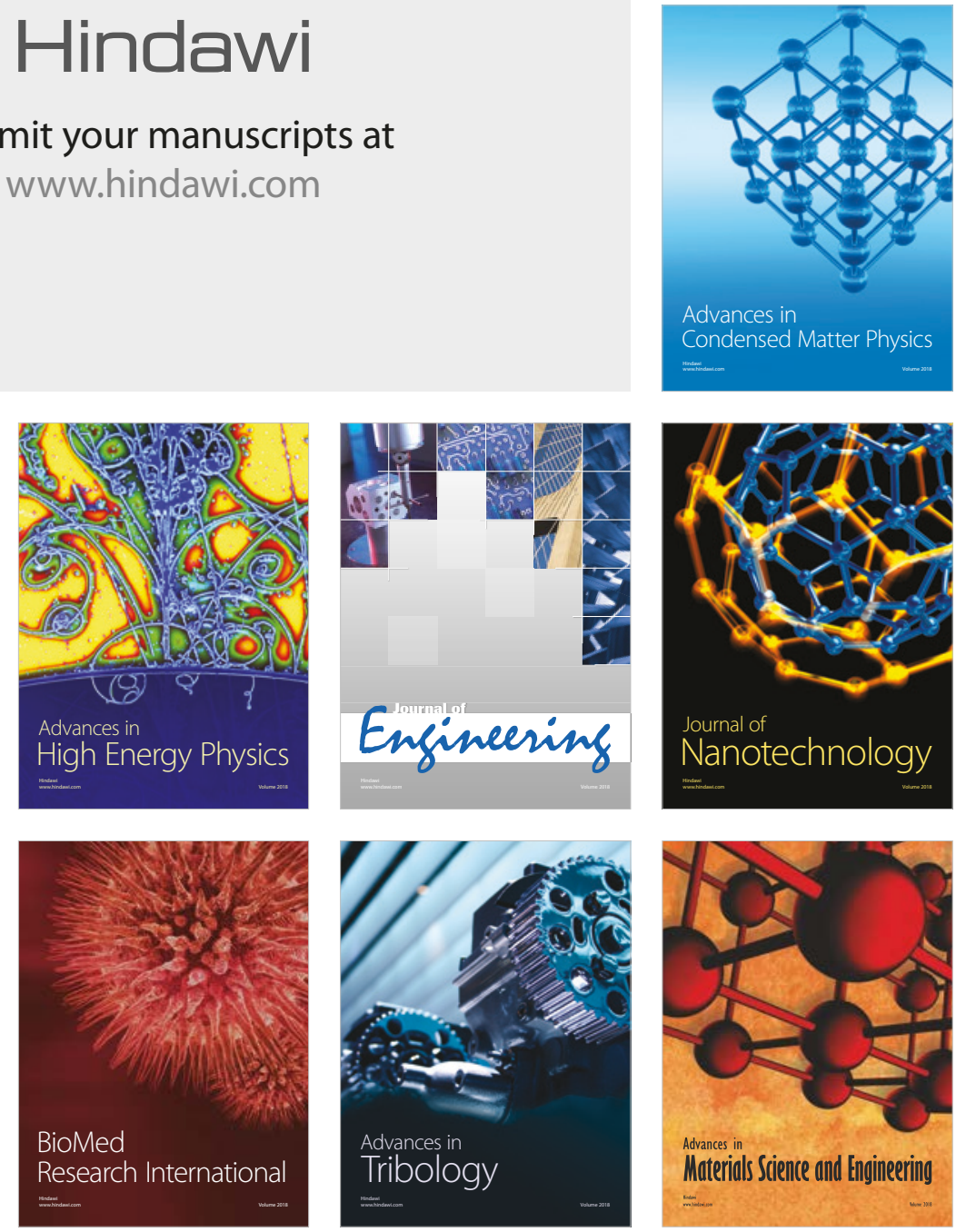